\title{
Environmental Impact on Early Generations Selection and Its Implications on Breeding Strategies in Rice
}

\author{
Oumarou Souleymane ${ }^{1}$, Massaoudou Hamidou ${ }^{1}$, Mahamadou Salifou $^{1}$, Baboucarr Manneh $^{2}$, \\ Eric Danquah ${ }^{3}$, Kwadwo Ofori ${ }^{3}$, \\ ${ }^{1}$ National Institute for Agronomic Research of Niger (INRAN). \\ ${ }^{2}$ Africa Rice center (ex-WARDA)/AfricaRice Sahel Station B.P. 96 Saint Louis/Senegal \\ ${ }^{3}$ School of Agriculture, College of Basic and Applied Sciences, University of Ghana.
}

*Corresponding Author: Souleymane Oumarou, National Institute for Agronomic Research of Niger, Niger Email: umarsou@gmail.com

\begin{abstract}
Genotype-environment interaction poses an outmost barrier to the breeders in the process of development of improves rice varieties. Understanding the causes and extent of Genotype-environment interaction is highly useful to frame breeding objectives, identifying ideal test locations, and formulating varietal release recommendations. The objectives of this study were to: (i) know the effect of environment on gene action, (ii) assess yield stability across environment, (iii) know the ideal environment to discriminate the F3 population and (iv) assess ideal genotype to discriminate the environment. Thus, 120 rice families, 4 parents and local check were evaluated on 2 saline environments. Collected data were analyzed using SAS software version 9.2 and Genstat $18^{\text {th }}$. Non significant effect of environment on gene action was noticed for all the traits, tiller excepted. The genotype by environment interaction was highly significant implying differential performance of families at different locations. However, there was crossover $G \times E$ interaction, suggesting that different winners can be evaluated in different environments.
\end{abstract}

Keywords: genotypes and environment, interaction, implication, rice breeding, Niger.

\section{INTRODUCTION}

Rice (Oryza sativa) is the most important food crop that supplies over $21 \%$ of the calorific demands of the world population (Fasahat et al. 2014). In developing new rice varieties, the main trait that breeders consider is grain yield (Fitzgerald et al. 2008). However the environment affects the expression of quantitative traits such as grain yield, and different environments can affect genotypes differently. Phenotypic values are classically divided into genotypic $(\mathrm{G})$, environmental (E) and genotype $\times$ environmental interaction $(\mathrm{G} \times \mathrm{E})$ effects (Hallauer and Miranda Fo 1988). The environment is the sum of total physical, chemical and biological factors that influence the development of an organism (Nadarajan and Gunasekaran 2005). The GE interaction, is defined by Cooper and Byth (1996) as the variation in relative performance of genotypes in different environments. Genotype-environment interaction poses a major barrier to the breeder in the process of improving variety (Sangodele et al. 2013). This is, because it complicates the selection of superior genotypes, thereby reduces genetic progress (Romagosa and Fox 1993). Thus, if GE interactions are present, breeders need to identify stable genotypes with relatively consistent performance across a range of environments (Ouk et al. 2007).

Several methods have been used to quantify the GE interaction for yield. These include contrasts, Regression on Mean Model, Additive Main and Multiplicative Interaction (AMMI) Model, Principal Component Axis (PCA) Model (Yan 2011) and GGE biplot model. The latter is used in this study to work out genotypes by environment interaction. This is because it is simpler and more informative (Yan 2011).

The objectives of this study were to: (i) understand the effect of environment on gene action, (ii) assess yield stability across environments, (iii) identify the ideal genotypes and environment for yield. 

Rice

\section{MATERIAL AND METHODS}

The study was carried out on two sites of Niger country namely, Saga with a latitude of $13^{\circ} 28^{\prime} \mathrm{N}$ and a longitude of $2^{\circ} 08^{\prime}$ and Sekoukou latitude of $13^{\circ} 15^{\prime} \mathrm{N}$ and a longitude of $2^{\circ} 22^{\prime}$. The soils characteristics are presented in the Table1.

Table 1: Physical and chemical characteristic of the study sites soils

\begin{tabular}{|l|l|l|l|l|l|l|l|l|}
\hline Sites & pH & SAR & CEC (meq/100g) & EC (dS/m) & Na/k (\%) & Clay (\%) & Silt (\%) & Sand (\%) \\
\hline Saga & 5.4 & 14.38 & 11.94 & 12.30 & 118.6 & 11.6 & 13.1 & 75.3 \\
\hline Sekoukou & 5.2 & 12.46 & 18.96 & 8.6 & 60.8 & 48.4 & 26.6 & 25 \\
\hline
\end{tabular}

$\mathrm{SAR}=$ sodium adsorption ration, $\mathrm{CEC}=$ cation exchange capacity, $\mathrm{EC}=$ electrical conductivity, $\mathrm{Na} / \mathrm{K}=$ sodium and potassium ration

Two salt tolerant genotypes: IRRI113 and NSIC RC106 (Souleymane et al. 2016) and two susceptible farmers varieties IR1526 and Gambiaka have been crossed in full diallel. The first generations $F_{1}$ from these crosses were bulked and selfed to get $12 \mathrm{~F}_{2}$ families (Kol-2, Kol-15, Kol-14, Kol-11, Kol-5, Kol-4, Kol-31, Kol-29, Kol-27, Kol-25, Kol-23, Kol-21). The $F_{2}$ families were advanced to have $F_{3}$ families. A random sample of one hundred and twenty (120) $\mathrm{F}_{3}$ families derived from $\mathrm{F}_{2}$ individual plants were taken for evaluation in farmer's field affected by salt problem. In addition 4 parents and a farmer preferred variety (NERICA-L49) served as check were also evaluated in the same condition. The experimental design was $25 * 5$ Alpha lattice with three replications. Each block was constituted with 25 lines with 10 plants on lines and each line was constituted of one $\mathrm{F}_{3}$ family. The inter-plant space was $0.2 \mathrm{~m}$ and the between line space was $0.5 \mathrm{~m}$. At the maturity plant height, total tillers per plant, reproductive tillers per plant, number of panicle, panicle weight, and paddy yield were scored. The time to $50 \%$ flowering, time to $85 \%$ maturity were also recorded (Souleymane et al. 2015). Data were analyzed using SAS software version 9.2. A general ANOVA was performed using SAS Glm procedure with random effect Model.

The Hayman diallel model (Hayman 1954) was used for gene action study. The model used is:

$\mathrm{Y}=\mathrm{U}+\mathrm{rep}+\mathrm{a}+\mathrm{b}+\mathrm{c}+\mathrm{d}+\mathrm{a}^{*}$ rep $+\mathrm{b}^{*}$ rep $+\mathrm{c}^{*}$ rep $+\mathrm{d}^{*}$ rep, where

- $\mathrm{U}=$ grand mean; rep= replication effects; $\mathrm{a}=$ additive effects; $\mathrm{b}=$ dominance effects;

$\mathrm{b}=$ is partitioned into: $\mathrm{b} 1$ that indicates direction of dominance (unidirectional if significant; equiv. to Parent vs. crosses contrast); b2, tests asymmetry of alleles; b3, shows that some dominance is peculiar to some crosses. $\mathrm{c}=$ additive maternal effects; $\mathrm{d}=$ maternal interaction effects;

- $\quad a * r e p+b * r e p+c * r e p+d * r e p=$ interaction of the reps with the model components.

Genstat software version $18^{\text {th }}$ was used for genotype and environmental interaction study. The GGE biplot methods were used for the analysis (Yan 2011).

\section{RESUltS}

The environments (sites) were significantly different for all the traits measured (Table 2). Highly significant differences also existed among F3 families. Family's performances were highly significantly influenced by environment effects. This is so because families and environment interaction was highly significant for all the traits.

Table 2: families and environment interaction

\begin{tabular}{|l|r|r|l|l|l|l|l|l|}
\hline Source & d.f. & Flw & Tnum & Pnum & height & Tpwt & Pwt & Gwt \\
\hline Env & 1 & $166821.84 * * *$ & $882752.6 * * *$ & $623944.43 * * *$ & $342190.56 * * *$ & $838150.7 * * *$ & $248.28 * * *$ & $342967.16 * * *$ \\
\hline Family & 124 & $1098.36 * * *$ & $2812.42 * * *$ & $2742.03 * * *$ & $1098.36 * * *$ & $4321.86 * * *$ & $8.15 * * *$ & $2833.79 * * *$ \\
\hline Env*family & 124 & $411.29 * * *$ & $2667.03 * * *$ & $2475.01 * * *$ & $411.29 * * *$ & $4434.37 * * *$ & $8.94 * * *$ & $3650.05 * * *$ \\
\hline
\end{tabular}

$* * *=$ very highly significant. Pwt = panicle weight, Tpwt = total panicle weight, Gwt = grain weight, Pnum = panicle number, Tnum= tiller number, and Flw= time to50\% flowering.

Effect of environment on gene action (additive, dominance, and maternal effect) existed but was not 
Environmental Impact on Early Generations Selection and Its Implications on Breeding Strategies in Rice

significant for all the traits measured (Figure 3). However for tiller number, significant interaction existed between dominance effect and the environment.

Table 3: genes action and environment

\begin{tabular}{|l|r|r|r|r|r|r|r|r|}
\hline Interaction & \multicolumn{1}{|c|}{ d.f. } & \multicolumn{1}{l|}{ Flw } & \multicolumn{1}{l|}{ Tnum } & \multicolumn{1}{l|}{ Pnum } & \multicolumn{1}{l|}{ height } & \multicolumn{1}{l}{ Tpwt } & Pwt & Gwt \\
\hline Env*a & 3 & $18.76 \mathrm{~ns}$ & $0.95 \mathrm{~ns}$ & $26.43 \mathrm{~ns}$ & $25.22 \mathrm{~ns}$ & $60.86 \mathrm{~ns}$ & $0.03 \mathrm{~ns}$ & $54.44 \mathrm{~ns}$ \\
\hline Env*b1 & 1 & $25.66 \mathrm{~ns}$ & $50.33 \mathrm{~ns}$ & $45.91 \mathrm{~ns}$ & $1.27 \mathrm{~ns}$ & $166.64 \mathrm{~ns}$ & $0.96 \mathrm{~ns}$ & $76.28 \mathrm{~ns}$ \\
\hline Env*b2 & 3 & $3.65 \mathrm{~ns}$ & $169.39 *$ & $107.97 \mathrm{~ns}$ & $13.06 \mathrm{~ns}$ & $163.89 \mathrm{~ns}$ & $0.61 \mathrm{~ns}$ & $91.47 \mathrm{~ns}$ \\
\hline Env*b3 & 2 & $3.32 \mathrm{~ns}$ & $4.93 \mathrm{~ns}$ & $4.23 \mathrm{~ns}$ & $6.62 \mathrm{~ns}$ & $6.37 \mathrm{~ns}$ & $0.01 \mathrm{~ns}$ & $0.27 \mathrm{~ns}$ \\
\hline Env*b & 6 & $7.21 \mathrm{~ns}$ & $94.73 \mathrm{~ns}$ & $63.05 \mathrm{~ns}$ & $8.95 \mathrm{~ns}$ & $111.84 \mathrm{~ns}$ & $0.47 \mathrm{~ns}$ & $58.54 \mathrm{~ns}$ \\
\hline Env*c & 3 & $8.00 \mathrm{~ns}$ & $18.35 \mathrm{~ns}$ & $35.39 \mathrm{~ns}$ & $0.25 \mathrm{~ns}$ & $192.60 \mathrm{~ns}$ & $0.28 \mathrm{~ns}$ & $130.65 \mathrm{~ns}$ \\
\hline Env*d & 3 & $2.01 \mathrm{~ns}$ & $18.09 \mathrm{~ns}$ & $23.34 \mathrm{~ns}$ & $10.07 \mathrm{~ns}$ & $57.25 \mathrm{~ns}$ & $0.08 \mathrm{~ns}$ & $22.18 \mathrm{~ns}$ \\
\hline
\end{tabular}

Pwt = panicle weight, Tpwt = total panicle weight, Gwt = grain weight, Pnum = panicle number, Tnum=tiller number, and Flw= time to50\% flowering.

The yield scatter plot (Figure 1) showed that the two sites were different and formed two distinct mega-environments. The angle between the two environment is slightly larger than $90^{\circ}$, implying that the genotype/environment interaction is moderately large. The environement one has a vector longer than environment two. This implies that the environment 1 discriminate more efficiently the families than environment 2. All the families were distant from the origine this means that they were highly responsive to the environment effect. The families which won in the differents sectors were 95,114 , 96, 17, 121 and 118. The families that performed well in environment 1 were 101, 95, 88, 92, 114, etc.... The families which won in the environment 2 were: $17,96,107,22,121$, etc...

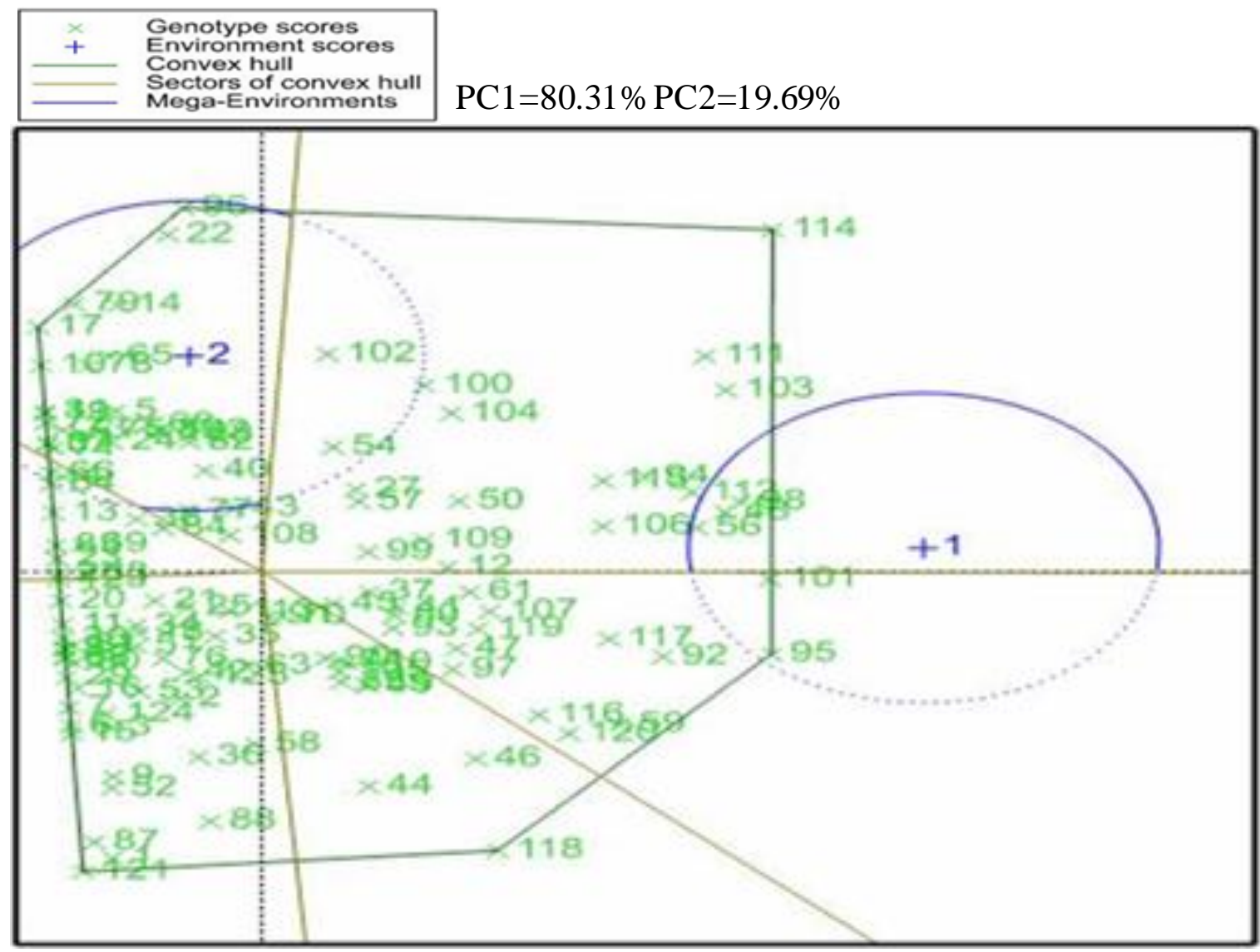

Figure 1: GGE biplot identification of winning genotypes and their related mega-environments

The ranking plot (Figure 2) shows a point (0) that is the average of all the environments and a line from the origin to the mean environment. Any families above the origin perform higher. The best families were: $114,111,103,112,84,11$, etc.... The most high yielding and stable families were: 111, 103. However, the family 114 that was the most performing in term of yield was more responsive to the environment. 
Environmental Impact on Early Generations Selection and Its Implications on Breeding Strategies in Rice

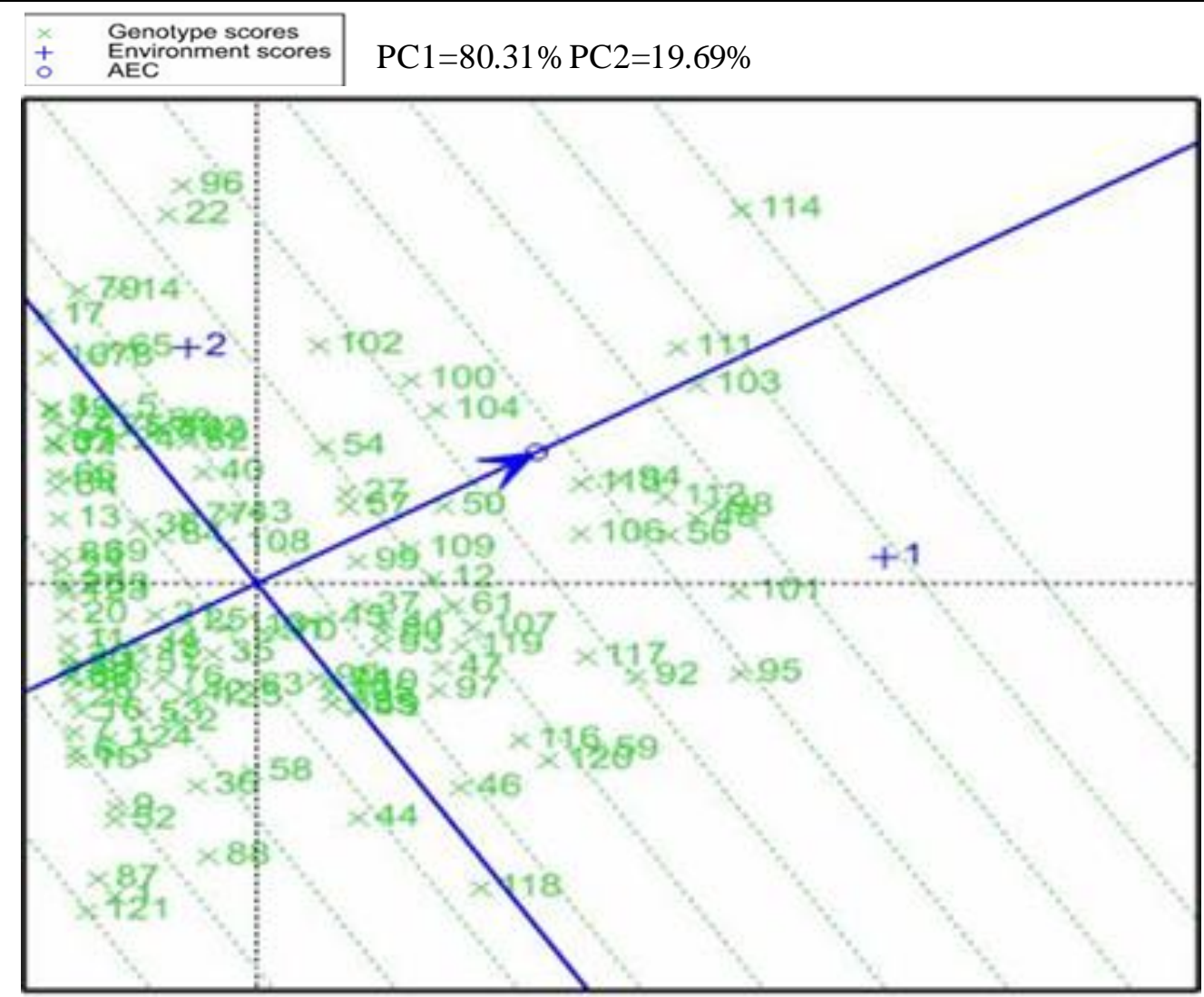

Figure 2: Stability of rice genotypes for yield

The genotypes comparison plot (Figure 3) shows the ideal genotype in the center. The family closer to the ideal is the best to discriminate the environments. Thus, family 114 is the ideal followed by 111 , 103 etc....

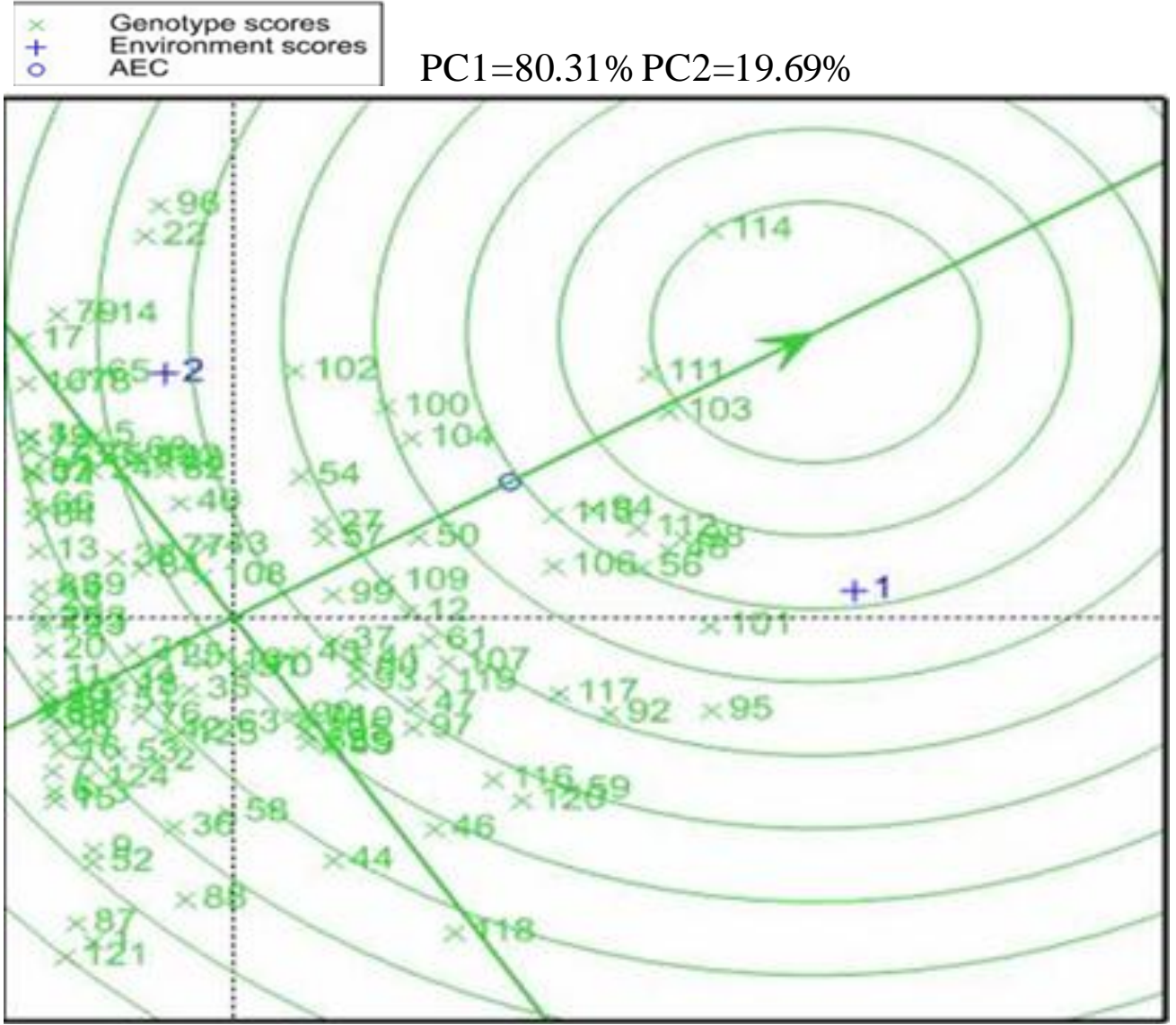

Figure 3: Identification of best families based on ideal family 

Rice

NB: AEC, average environment coordination

The environment comparison plot (Figure 4) shows that the best environment to discriminate the families was the environment 1 . This is because it is the closer to the ideal environment.

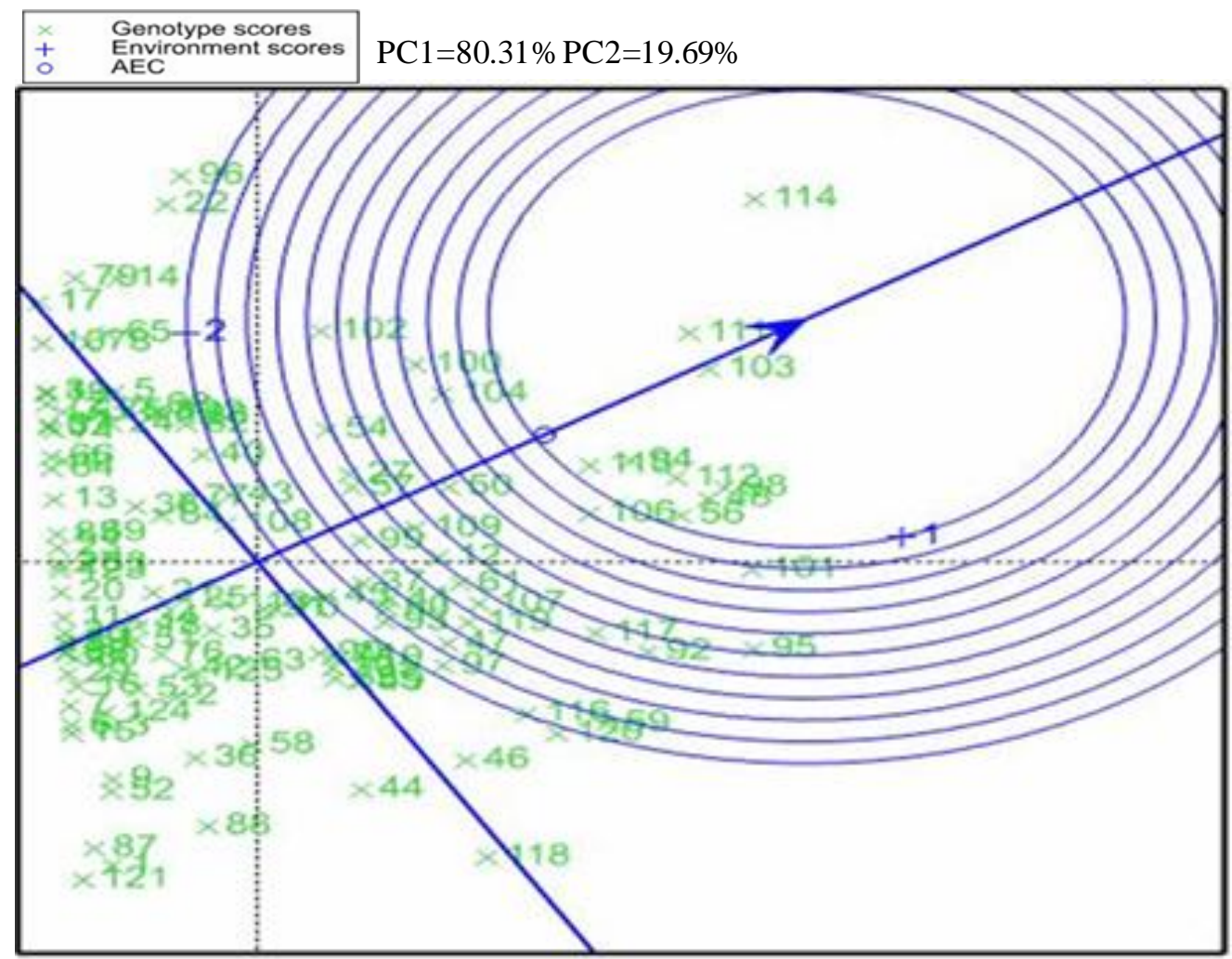

Figure 4: Identification of best environments based on ideal test environment

NB: $\mathbf{A E C}=$ average environment coordination

\section{DISCUSSION}

Understanding the causes and extent of $\mathrm{G} \times \mathrm{E}$ interaction is highly useful to frame breeding objectives, identifying ideal test locations, and formulating varietal release recommendations (Krishnamurthy et al. 2017). It is also of paramount importance to evaluate the adaptability and stability of the genotypes.

Results showed significant differences among location. This implied environments prevailing at the two sites were dissimilar. The genotype by environment interaction was highly significant for all the traits. This implied differential performance of families at different locations (Simmonds Smartt, J.). This may be due to the variability salt stress level across environments and within the same environment. Significant differences of environments increase substantially genotype by environment interaction and can reduce selection gain (Betrán et al. 2004; Cooper et al. 2006). According to Bose et al. (2012) highly significant genotype $\times$ environment $(\mathrm{G} \times \mathrm{E})$ interaction suggests that the genotypes interacted considerably with environmental conditions. Thus, significant genotype and environment necessitates more testing over larger number of locations (multi-environment trials) to evaluate genotype adaptation of fixed lines in the future (Cooper et al. 1999). Hence, according to Grando and Ceccarelli (2009) salinity is unpredictable and variable. There was crossover $\mathrm{G} \times \mathrm{E}$ interaction: rank of the genotypes changes in different environments, suggesting that different winners can be evaluated in different environments (Braun et al. 1996; Troyer 1996; Yan and Hunt 2000; Yan and Tinker 2006). There was a location (environment 1) that best discriminates the genotypes. That environment (Saga) should be used to improve the selection efficiency.

According to Singh et al. (2010) genotypes with a high yield mean, under stress environments are the most suitable, stable and adaptable for sustainable productivity in problem soils. The result results showed that the most high yielding and stable families were: 111, 103. These families should be advanced for lines fixation and release to farmers. 

Rice

According to Cooper et al. (1999) $\mathrm{G} \times \mathrm{E}$ interaction acts to reduce heritability. Thus, where $\mathrm{G} \times \mathrm{E}$ interactions exist, a condition for any estimate of heritability to be reliable is that the results must be based on a sample of environments that are representative (Cooper et al. 2006).

\section{CONCLUSION}

Rice lines performances were highly and significantly influenced by environments effects. The environments also affected differently lines yields implying environments prevailing at the two sites were dissimilar. There was crossover $\mathrm{G} \times \mathrm{E}$ interaction suggesting that different winners can be evaluated in different environments. The environment one (Saga) has a vector longer than environment two. Thus, is discriminate more efficiently the families than environment2 (Sekoukou). The most high yielding and stable families were: 111,103 . However the family 114 that was the most performing in term of yield was more responsive to the environment effect. However, family 114 is the ideal followed by 111, 103 etc.... The best environment to discriminate the families was the environment 1 .

\section{REFERENCES}

Betrán, FJ, Bänziger, M \& Menz, M. 2004. Corn breeding. In: Smith, W, Betrán, FJ \& Runge, E (eds.) Corn: Origin, history, technology, and production. New York, USA, John Wiley \& Sons.

Bose, LK, Nagaraju, M \& Singh, ON. 2012. Genotype x environment interaction and stability analysis of lowland rice genotypes. Journal of Agricultural Sciences, 57: 1-8.

Braun, HJ, Rajaram, S \& Vanginkel, M. 1996. Cimmyt's approach to breeding for wide adaptation. Euphytica, 92: 175-183.

Cooper, M \& Byth, DE. 1996. Understanding plant adaptation to achieve systematic applied crop improvement: A fundamental challenge. In: Cooper, M \& Hammer, GL (eds.) Plant adaptation and crop Wallingford: CABI Publishing.

Cooper, M, Podlich, DW \& Fukai, S. 1999. Combining information from multienvironment trials and molecular markers to select adaptive traits for yield improvement of rice in water-limited environments. In: Ito, O, O'toole, J \& Hardy, B (eds.) Genetic improvement of rice for waterlimited environments. Los Baños, Philippines: IRRI.

Cooper, M, Van Eeuwijk, FA, Chapman, SC, W., PD \& Löffler, C. 2006. Genotype-by-environment interactions under water-limited conditions. In: Ribaut, JM (ed.) Drought adaptation in cereals. Binghampton, USA, Haworth Press.

Fasahat, P, Muhammad, K, Abdullah, A, Bhuiyan, AR, Ngu, MS, Hugh, G, Gauch, JR \& Ratnam, W. 2014. Genotype $\times$ environment assessment for grain quality traits in rice. Communications in Biometry and Crop Science, 9: 71-82.

Fitzgerald, MA, Sackville-Hamilton, NR, Calingacion, MN, Verhoeven, HA \& Butardo, VM. 2008. Is there a second gene for fragrance in rice? . Plant Biotechnology Journal 6: 416-423.

Grando, S \& Ceccarelli, S. 2009. Breeding for quantitative variables part 3: Breeding for resistance to abiotic stresses. In: Ceccarelli, S, Guimarães, EP \& Weltzien, E (eds.) Plant breeding and farmer participation. Rome: FOOD AND AGRICULTURE ORGANIZATION OF THE UNITED NATIONS.

Hallauer, AR \& Miranda Fo, JB. 1988. Quantitative genetics in maize breeding. 2nd edition. Ames, USA, Iowa state University press.

Hayman, BI. 1954. The theory and analysis of diallel crosses. A .R. C. Unit of Biometrical Genetics, Department of Genetics, University of Birmingham.

Krishnamurthy, SL, Sharma, PC, Sharma, DK, Ravikiran, KT, Singh, YP, Mishra, VK, Burman, D, Maji, B, Mandal, S, Sarangi, SK, Gautam, RK, Singh, PK, Manohara, KK, Marandi, BC, Padmavathi, G, Vanve, PB, Patil, KD, Thirumeni, S, Verma, OP, Khan, AH, Tiwari, S, Geetha, S, Shakila, M, Gill, R, Yadav, VK, Roy, SKB, Prakash, M, Bonifacio, J, Ismail, A, Gregorio, GB \& Singh, RK. 2017. Identification of megaenvironments and rice genotypes for general and specific adaptation to saline and alkaline stresses in india. Nature, 7: 7968-7981.

Nadarajan, N \& Gunasekaran, LM. (2005). Quantitative genetics and biometrical techniques in plant breeding, New Delhi, Kalyani publishers. pp. 223-241. 
Ouk, M, Basnayake, J, Tsubo, M, Fukai, S, Fischer, KS, Kang, S, Men, S, Thun, V \& Cooper, M. 2007. Genotype by environment interactions for grain yield associated with water availability at flowering in rainfed lowland rice. Field Crops Research 101: 145-154.

Romagosa, I \& Fox, PN. 1993. Genotype $\times$ environment interaction and adaptation. In: Hayward, MD, Bosemark, NO \& Romagosa, I (eds.) Plant breeding: Principles and prospects. London: Chapman \& Hall.

Sangodele, EA, Hanchinal, RR, Hanamaratti, NG, Shenoy, V, Mahantashivayogayya, K, Surendra, P \& Ibrahim, M. 2013. Genotype $\times$ environment interaction (gei) and stability analysis of backcross inbred lines (bils) derived from swarna $\times$ wab 450 inter cross under rainfed ecosystem in north karnataka state of india. Rice Genomics and Genetics, 4: 22-27.

Simmonds, NW. (Smartt, J.). Principles of crop improvement, London-United Kingdo, Blackwell Science Ltd.

Singh, RK, Redoña, E \& Luzminda Refuerzo, L. 2010. Varietal improvement for abiotic stress tolerance in crop plants: Special reference to salinity in rice. In: Bohnert, HJ (ed.) Abiotic stress adaptation in plants: Physiological, molecular and genomic foundation. IRRI.

Souleymane, O, Manneh, B, Nartey, E, Ofori, K \& Danquah, E. 2015. Genetic mechanisms controlling salt tolerance in $\mathrm{f} 3$ populations of rice. International Journal of Plant Breeding and Genetics, 9: 262-268.

Souleymane, O, Nartey, E, Manneh, B, Danquah, E \& Ofori, K. 2016. Phenotypic variability of 20 rice genotypes under salt stress. International Journal of Plant Breeding and Genetics, 10: 4551.

Troyer, AF. 1996. Breeding for widely adapted, popular maize hybrids. Euphytica, 92: 163-174.

Yan, W. 2011. Gge biplot ve. Ammi graphs for genotypes-by environmental data analysis. Journal of the Indian Society of Agricultural Statistics 65: 181-193.

Yan, W \& Hunt, L. 2000. Genetype by environment interaction and crop yield. Plant Breeding Reviews, 16: 137-177.

Yan, W \& Tinker, NA. 2006. Biplot analysis of multi-environment trial data: Principles and applications. Can. J. Plant Sci., 86: 623-645.

Citation: O. Souleymane, " Environmental Impact on Early Generations Selection and Its Implications on Breeding Strategies in Rice ", International Journal of Advanced Research in Botany , vol. 3, no. 3, p. 7, 2017. http://dx.doi.org/10.20431/2455-4316.0303001

Copyright: (C) 2017 Authors. This is an open-access article distributed under the terms of the Creative Commons Attribution License, which permits unrestricted use, distribution, and reproduction in any medium, provided the original author and source are credited. 